\title{
Economic analysis of rice and common bean production in succession to green manure crops and mecahnical soil decompression in Brazilian Savannah ${ }^{1}$
}

\author{
Vagner do Nascimento ${ }^{2 *}$, Orivaldo Arf ${ }^{2}$, Maria Aparecida Anselmo Tarsitano ${ }^{2}$, Nayara Fernanda Siviero Garcia $^{2}$, \\ Mariele de Souza Penteado ${ }^{2}$, Michelle Traete Sabundjian ${ }^{2}$
}

10.1590/0034-737X201663030006

\begin{abstract}
The previous cultivation of green manures and mechanical soil decompression are options to minimize compaction of the topsoil in no-tilage system (NTS) set in different production systems in the Brazilian Savannah. In addition, it is essential to relate these agricultural practices with the economic benefits generated through the production cycles. The objective of this study was to evaluate economically the effect of sporadic mechanical decompression of the soil and previous cultivation of green manure in the production and net gain margin of upland rice and "winter" common bean, under sprinkler irrigation, in NTS in lowland Brazilian savannah. This study was developed in the 2012/13 harvest and 2013 winter in Selvíria, state of Mato Grosso do Sul, in an clay texture Oxisol in the savanah in the state of Mato Grosso do Sul, in a randomized block design arranged in a $5 \times 2$ factorial arrangement with four replications. The treatments were a combination of five green manures (fallow (control), Cajanus cajan, Crotalaria juncea, Pennisetum glaucum and Urochloa ruziziensis) with and without mechanical soil scarification. The yields of upland rice and common bean grains were not influenced by the previous green manure cultivation; the upland rice grown in succession to Cajanus cajan in the presence of mechanical soil scarification provided greater increase in grain yield and higher gross margin profit. Beans cultivated in succession to Crotalaria juncea and Pennisetum glaucum in the presence of mechanical soil scarification, followed by rice cultivation, provided greater increases in grain yield and gross profit margins.
\end{abstract}

Key words: Phaseolus vulgaris L.; Oryza sativa L.; profit margin; cover crops; sprinkler irrigation; no-tilage system.

\section{RESUMO}

\section{Análise econômica da produção de arroz e feijão em sucessão a cultivos de adubos verdes e descompactação mecânica no cerrado}

O cultivo antecessor de adubos verdes e a descompactação mecânica do solo são opções para minimizar a compactação da camada superficial do solo em sistema plantio direto (SPD) implantado, em diversos sistemas de produção no cerrado. Além disso, é essencial relacionar estas praticas agrícolas com os benefícios econômicos gerados. Assim, este trabalho objetivou avaliar economicamente o efeito da descompactação mecânica esporádica do solo e cultivo antecessor de adubos verdes, na produtividade e margem liquida do ganho para o arroz de terras altas e feijão "de inverno", sob irrigação por aspersão, em SPD em área de cerrado de baixa altitude. Este estudo foi desenvolvido na safra 2012/13 e no inverno de 2013 em Selvíria, MS, em um Latossolo Vermelho distrófico de cerrado Sul Mato Grossense de textura argilosa, com delineamento em blocos casualizados disposto em esquema fatorial $5 \times 2$, com quatro repetições. Os tratamentos foram constituídos pela combinação de cinco adubos verdes (pousio (controle), Cajanus cajan, Crotalaria

Submitted on June $9^{\text {th }}, 2015$ and accepted on March $3^{\text {rd }}, 2016$.

${ }^{1}$ Part of doctoral's thesis of the first author. Study developed with financial resources of FAPESP.

${ }^{2}$ Universidade Estadual Paulista "Júlio de Mesquita Filho", Faculdade de Engenharia de Ilha Solteira, Departamento de Fitotecnia, Tecnologia de Alimentos e Sócio-Economia, Ilha Solteira, São Paulo, Brazil.vagnern@gmail.com; arf@agr.feis.unesp.br; maat@agr.feis.unesp.br; nayaragarcia.agro@gmail.com; mariele.souzap@gmail.com; michelletraete@hotmail.com *Corresponding author: vagnern@gmail.com 
juncea, Urochloa ruziziensis e Pennisetum glaucum) com e sem escarificação mecânica do solo. As produtividades de grãos do arroz e feijão não foram influenciadas pelo cultivo antecessor de adubos verdes; o arroz de terras altas cultivado em sucessão a Cajanus cajan, na presença de escarificação mecânica do solo, proporcionou maior acréscimo de produtividade de grãos e maior margem de ganho bruta. O feijão cultivado em sucessão a Crotalaria juncea e Pennisetum glaucum, na presença de escarificação mecânica do solo, seguida de cultivo do arroz, proporcionaram maiores acréscimos na produtividade de grãos e nas margens de ganho brutas.

Palavras-chave: Phaseolus vulgaris L.; Oryza sativa L.; margem de ganho; plantas de cobertura; irrigação por aspersão; sistema plantio direto.

\section{INTRODUCTION}

Rice and beans have economic, social and nutriton importance due to the daily consumption habit. The per capita annual consumption of rice in Brazil is between 25 and $50 \mathrm{~kg}^{-1}$ inhabitant ${ }^{-1}$ year $^{-1}$ (FAO, 2011), being an excellent source of carbohydrates, in its natural form, but it can also be an important source of proteins, mineral salts (mainly phosphorus, iron and calcium) and vitamins of $\mathrm{B}$ complex such as $\mathrm{B}_{1}$ (thiamine), $\mathrm{B}_{2}$ (riboflavin) and $\mathrm{B}_{3}$ (niacin). However, in relation to beans, out of ten Brazilians, seven consume beans daily. Moreover, the grain, besides being typical of the Brazilian cuisine, is a source of vegetable protein, $\mathrm{B}$ vitamins, mineral salt, iron, calcium and phosphorus (Brazil, 2013). For the total Brazilian harvest of rice and beans in 2014/15, a total cultivated area of 2.4 and 3.2 million hectares was estimated, and the domestic production of 12.2 and 3.3 million tons of grains, and average yield of 5,182 and 1,044 ha- ${ }^{-1}$, respectively, according to Conab (2015).

In an established no-tillage system (NTS), because of the small mobilization in the soil, compactation issues have been occuring with greater intensity and extenion in in the surface layers. This occurs because of the compression process caused by machinary traffic in agricultural operations where the soil at moisture conditions above the ideal, especially in clay soils, and also due to no soil mobilization, combined with higher water retention in the soil, determining a short period of time with adequate moisture for mechanized operations (Araújo et al., 2001).

The sporadic mechanical scarification of established no-tillage soil can be a viable alternative to minimize the physical limitations in the surface layers of soil to plant growth. Some studies have shown significant increases in crop yields in soils under scarified non-tillage (Câmara \& Klein, 2005; Vieira, 2006). This practice increases porosity and decreases soil density (Reichert et al., 2009) while the compacted layers are broken up to a depth of $0.30 \mathrm{~m}$. As a result, scarification increases the rate of infiltration and water storage capacity. However, nothing prevents the decompressed soil to be used again in the no-tillage system since the decompression process is suitably performed with well regulated equipment (scarifiers and escarifying rods) with thin stems and narrow tip, so they revolve the soil as little as possible, trying to break the soil in its natural break up plan and keeping most of the plant debris on the soil surface (Salton et al., 1998).

The cultivation of green manures with root systems that exploit different volumes of soil provides nutrient cycling (Boer et al., 2007). Since the decomposition of vegetal debris of these plants release nutrients that contribute to increases in corn yields (Lara Cabezas et al., 2004) and soybean (Carvalho et al., 2004) or maintaining the productivity of these crops (Andrioli, 2004; Bertin et al., 2005). According to Tanaka et al. (1992), the use of velvet bean, lablab and crotolaria as green manure provided significant increases in yields of rice, beans and soybean in succession. So, there is a need to adjust the production system, taking into account the previous crops and sporadic mechanical descompactation of the soil to obtain the highest profit margin, as failure in rice and bean crop is often determined by compactation on the surface layer of soil in established non-tilage systems, altering the quality of the soil because it changes the flow of water and air and the dynamics of soil nutrients, promoting the reduction of productivity of crops in several production systems.

In studies with economic analysis in corn crop in notillage system after green manures in Red Latosol soil, Silva et al. (2007) found that corn crop in succesion to crotolaria provided greater physical and economic yield of grains, compared to corn in successsion to millet crop and fallow.

To use in a rational manner the production systems created from the established no-tillage system is needed the knowledege of various fields of study. Among them, financial management of the property stands out, which is important for assessing the profitability of practices 
used within the production systems, assisting in decision making of investments. Economic information of a crop is of fundamental importance to the farmer since it helps in the combination of the resources used in its production, in order to obtain better results (Crepaldi, 1998).

Thus, studies that contribute to an appropriate recommendation from not only the agronomic point of view but also from economic production system over its previous use of green manures and sporadic mechanical decompression of the soil, particularly with compaction problems on the superficial layer are needed. The objective of this study was to estimate the increase in productivity and net monetary margin with sporadic mechanical decompression of the soil and previous crop of green manure on the production of upland rice and winter beans under sprinkler irrigation in no tillage system implanted 12 years ago, in lowland Brazilian Savannah.

\section{MATERIALAND METHODS}

This study was developed in the 2012/13 crop and 2013 winter in Selvíria, state of Mato Grosso do Sul, located at $51^{\circ} 22^{\prime} \mathrm{W}$ and $20^{\circ} 22^{\prime}$ ' south, $335 \mathrm{~m}$ above seal level in a clay texture oxisol, epi-eutrophic alic, according to EMBRAPA (2013) classification. The average annual values of rainfall, temperature and relative humidity are $1,370 \mathrm{~mm}, 23.5^{\circ} \mathrm{C}$ and $70-80 \%$, respectively. According to Köppen, the climate type is Aw, characterized as humid tropical, with rainy season in Summer and dry season in Winter. The experimental area had been used for 12 years in no-tillage system, cultivated in 2009/10, 2010/11 and 2011/12 with corn (Summer) and beans (Winter) crops, except in the winter of 2011/12 when the area was maintained in fallow. In 2012/13, management was carried out with mechanical soil descompactation, cultivation of green manure in the spring (September to November) and rice (Summer) and "Winter" beans.

Before the experiment setting up, chemical and physical characterization of soil was carried out in June $14^{\text {th }}, 2012$ (Table 1). For soil analysis, a composite sample, originated from 20 simple soil deformed samples was removed from all experimental area at the stratified layers of 0.00-0.05, 0.05-0.10, 0.10-0.20 and 0.20-0.40 m. As for physical analysis, non-deformable soil samples were taken at 10 random sites in the experimental area, in the layers already cited, with $10^{-4} \mathrm{~m}^{-3}$ volumetric rings.

The experimental design was a randomized block arranged in a 5 x 2 factorial design, with four replications. The treatments were a combination of five green manures (fallow (control), Cajanus cajan, Crotalaria juncea, Urochloa ruziziensis and Pennisetum glaucum) with and without mechanical soil scarification. In fallow with and without soil scarification, growth of natural vegetation of weeds was allowed. Each plot consisted of $12 \mathrm{~m}$ in length and $7 \mathrm{~m}$ of width.

Thus, after the initial characterization on June $10^{\text {th }}$, $2012,1,600 \mathrm{~kg} \mathrm{ha}^{-1}$ of dolomitic limestone was applied all over the experimental area, with $85 \%$ PRNT using equipment with broatcast distributer. Soil tillage was carried out using scarificator in some of the experimental area on August, $9^{\text {th }}, 2012$, before the sowing of green manure (GM), with seven-rod scarifier reaching the working depth of $0.30 \mathrm{~m}$ and width of cut range $2.1 \mathrm{~m}$. In the scarified parts, an operation with levelling disk was carried out.

All green manures were hand sown on August, $14^{\text {th }}$, 2012 without fertilization, with spacing between rows of $0.45 \mathrm{~m}$. Sowing densities used for Cajanus cajan were 60 $\mathrm{kg} \mathrm{ha}^{-1}$, Crotalaria juncea and Pennisetum glaucum of 30 $\mathrm{kg} \mathrm{ha}^{-1}$ and for Urochloa ruziziensis, $12 \mathrm{~kg} \mathrm{ha}^{-1}$. All green manures were dessicated on day 68 after sowing (DAS) with glyphosate (1.440 $\mathrm{g} \mathrm{ha}^{-1}$ a.i. $)+2,4-\mathrm{D}\left(670 \mathrm{~g} \mathrm{ha}^{-1}\right.$ a.i. $)$. After 10 days, all GM were mecanchally ground, with cutting height of $0.10 \mathrm{~m}$. On June $6^{\text {th }}, 2013$, additional dessication was carried out with paraquat (1.314 $\mathrm{g} \mathrm{ha}^{-1}$ a.i.).

Mechanical sowing of rice was held on November, $13^{\text {th }}, 2012$, conducted from November to March, under sprinkler irrigation, following the same experimental design and treatments. The basic fertilizer in planting furrows consisted of $250 \mathrm{~kg} \mathrm{ha}^{-1}$ of 06-30-10, following the recommendation of Cantarella \& Furlani (1996). Cultivar IAC 203, with the number of certified seed, needed for a

Table 1: Chemical and physical characteristics of the soil in the experimental area in the evaluated layers before experiment setting up

\begin{tabular}{|c|c|c|c|c|c|c|c|c|c|c|c|c|}
\hline \multirow[b]{3}{*}{ Depth (m) } & \multicolumn{7}{|c|}{ Chemical characteristics } & \multicolumn{5}{|c|}{ Physical characteristics } \\
\hline & \multirow{2}{*}{$\frac{P}{\mathrm{mg} \mathrm{dm}^{-3}}$} & \multirow{2}{*}{$\frac{\text { O.M. }}{\mathrm{g} \mathrm{dm}^{-3}}$} & \multirow{2}{*}{$\frac{\mathrm{pH}}{\mathrm{CaCl}_{2}}$} & $\mathbf{K}$ & $\mathbf{C a}$ & Mg & Al & \multirow{2}{*}{$\begin{array}{l}\mathrm{V} \\
\%\end{array}$} & Ma & Mi & $\mathbf{T P}$ & \multirow{2}{*}{$\frac{\mathrm{SD}}{\mathrm{Mg} \mathrm{dm}^{-3}}$} \\
\hline & & & & \multicolumn{4}{|c|}{$\left(\mathrm{mmol}_{\mathrm{c}} \mathrm{dm}^{-3}\right)$} & & \multicolumn{3}{|c|}{$\mathbf{m}^{3} \mathbf{m}^{-3}$} & \\
\hline $0.00-0.05$ & 29 & 24 & 5.9 & 3.5 & 41 & 25 & 0 & 79 & 0.08 & 0.36 & 0.44 & 1.49 \\
\hline $0.05-0.10$ & 6 & 17 & 4.9 & 1.8 & 17 & 12 & 2 & 48 & 0.06 & 0.35 & 0.41 & 1.56 \\
\hline $0.10-0.20$ & 38 & 15 & 4.5 & 1.3 & 10 & 7 & 6 & 33 & 0.07 & 0.35 & 0.42 & 1.54 \\
\hline $0.20-0.40$ & 7 & 13 & 4.8 & 1.4 & 10 & 8 & 2 & 40 & 0.10 & 0.36 & 0.46 & 1.42 \\
\hline
\end{tabular}

Depth: soil depth (metter); P: available phosphorus (resina); O.M.: organic matter; exchangeable K, Ca, $\mathrm{Mg}$ and $\mathrm{Al}$; V(\%): base saturation; Ma: Macroporosity, Mi: Microporosity; PT: Total porosity and SD: soil density. 
stand of 180 plants $\mathrm{m}^{-2}$ was used. Topdressing nitrogen fertilization was performed 30 days after emergence (DAE) of seedlings at a dose of $60 \mathrm{~kg} \mathrm{ha}^{-1} \mathrm{~N}$, using ammonium sulfate. Other crops and phytosanitary treatments were those usually recommended to upland rice crop for the region. Harvest was carried out on March, $4^{\text {th }}, 2013$.

On March $4^{\text {th }}, 2013$, the herbicide glyphosate $(1,440 \mathrm{~g}$ ha ${ }^{-1}$ a.i.) was applied. Following that, mechanical sowing of beans was performed on May, $3^{\text {rd }}, 2013$, and conducted from May to August, under sprinkler irrigation, following the same experimental design and treatment. The plots consisted of 14 lines of $12 \mathrm{~m}$ in length, considered as useful area, 12 rows in the center, leaving $0.5 \mathrm{~m}$ at both ends of each line. The spacing between rows was $0.45 \mathrm{~m}$ with seed distribution allowing to obtain 12 plants $\mathrm{m}^{-1}$.

Basic fertilizer in planting furrows consisted of $250 \mathrm{~kg}$ ha $^{-1}$ of 04-30-10 $+0.3 \% \mathrm{Zn}$, following recommendations of Ambrosano et al. (1997). Nitrogen fertilization was performed at $19 \mathrm{DAE}$ of seedlings at a dose of $60 \mathrm{~kg} \mathrm{ha}^{-1}$ $\mathrm{N}$, using ammonium sulfate. Perola cultivar with type III plants and carioca type grain were used. Seeds were treated just prior sowing with carboxin + thiram $(50+50 \mathrm{~g}$ a.i. per $100 \mathrm{~kg}$ of seed). At $12 \mathrm{DAE}$, post-emergence herbicide Bentazon ( $720 \mathrm{~g}$ a.i. ha $\left.{ }^{-1}\right)$ was used. Other cultural and phytosanitary practices were those usually recommended for bean crop for the region. Harvest was carried out on August, $15^{\text {th }}, 2013$.

The yield of rice grains was determined by weighing the grain from the useful area of the plot, correcting the moisture to $13 \%$ and converting it into $\mathrm{kg} \mathrm{ha}^{-1}$. As for evaluation of bean grain yield, plants were pulled out from the useful area of each plot and left to dry in unshaded area. After drying, they were submitted to mechanical track, the beans were weighed and the data trasnsformed into $\mathrm{kg} \mathrm{ha}^{-1}$ (13\% wet basis).

As for the economic analysis, the technique of partial budgeting, described in Noronha (1987) was used, and also in analysis of experiments carried out by Teixeira Filho et al. (2010), Binotti et al. (2010) and Sabundjian, et al. (2014). Partial budgeting is used to analyze decisions involving partial changes in the organization of a productive activity. The objective is to compare the increase in costs with the benefits of the decision. The best alternative is that offering greater net benefits or profit margins (Teixeira Filho et al., 2010). The average yields and costs were assessed. The costs of the seeds were obtained through pieces of information from supliers of the region, being from seeds of Cajanus cajan ( $\mathrm{R} \$ 10.06$ ), Crotalariajuncea $(\mathrm{R} \$ 13.50)$, Urochloa ruziziensis ( $\mathrm{R}$ \$13.29) and Pennisetum glaucum $(\mathrm{R} \$ 1.73)$ per $\mathrm{kg}$, during the harvest of 2013. The cost of scarification operation was $R \$ 60.00$ and the sowing of green manure was $R \$ 100.00$, based on Agrianual (2014). The values obtained with the costs for each treatment were divided by the rice (50\%) and bean (50\%) crops. Based on the average grain yield of each treatment, the increase in the yield was estimated provided by the use of green manure compared to the control (fallow with and without mechanical soil scarification).

The production value in each treatment was obtained by multiplying the additional yield by the average price received by producers of rice in husk and "Winter" beans of the study area. The profit margin was obtained by subtracting the production value by the cost obtained with mechanical soil scarification, the kilogram of seeds of GM and sowing of GM for each treatment. The price of rice and beans $(60 \mathrm{~kg} \mathrm{bag})$ refers to the average price received by producers during the month of harvest in the growing crop, which was $\mathrm{R} \$ 45.67 \mathrm{bag}^{-1}$ for rice and $\mathrm{R} \$$ $147.49 \mathrm{bag}^{-1}$ for beans, both in the crop years (IEA, 2015). Average prices were deflated by the General Price Index Internal Availability (IGP-DI) - published by the Getulio Vargas Foundation.

\section{RESULTS AND DISCUSSION}

Costs with green manure, mechanical decomposition, quantities of green manure seeds, rice and bean grains yield, increases in grain yield, production value and costs of seeds and sowing operations of GM and mechanical soil scarification per hectare are shown in Table 2. It is found that upland rice cultivated in succession to Cajanus cajan with $\left(6,074 \mathrm{~kg} \mathrm{ha}^{-1}\right)$ and without $\left(5,154 \mathrm{~kg} \mathrm{ha}^{-1}\right)$ mechanical soil scarification, in addition to Crotalaria juncea with scarification $\left(5,015 \mathrm{~kg} \mathrm{ha}^{-1}\right)$ provided greater increases in the yield of rice grains in relation to other GMs (Table 2). These results evidence the potential of Cajanus cajan, regardless of scarification, in providing greater cycling and release of nutrients for rice grown in succession. Rice grain yields were higher than those found by Pacheco et al. (2013), who found that the previous crop of Urochloa ruziziensis (1,554 $\left.\mathrm{kg} \mathrm{ha}^{-1}\right)$ was the best option of green manure for rice, explaining that low productivity was due to the occurrence of water deficit (pre-flowering), different from the experiment in at matter since it had been irrigated. However, according to Pacheco et al. (2011) who obtained higher rice yields in no-tillage system on haystacks of Pennisetum glaucum and Urochloa ruziziensis.

Among the alternatives to minimize the effects of the thickening of soil particles, it is essential to use decompressor crops with abundant and vigorous root system, which provide the most efficient disruption of the compacted layer, providing improved stability of aggregates, thus increasing soil porosity and improving the production system, resulting in increased yield of 
crops in succession (Villamil et al., 2006). Among the decompressor species of plants, Cajanus cajan stands out for presenting deep root system, able to grow in soils with a tendency to form crusts on the surface (Brazaca et al., 1996), with good potential to absorb water and the possibility of cycling of nutrients from deeper layers (Alvarenga et al., 1995).

Regarding the productivity of "Winter" bean obtained in the treatments (Table 2), it was found that greater increases of bean grain yield occured in previos crops of Crotalaria juncea $\left(2,381 \mathrm{~kg} \mathrm{ha}^{-1}\right)$ and Pennisetum glaucum $\left(2,158 \mathrm{~kg} \mathrm{ha}^{-1}\right)$ with mechanical soil scarification, evidencing that the previous crop of Crotalaria juncea and Pennisetum glaucum associated with the operation of mechanical soil scarification interacted positively. Results contrary to that presented by Collares et al. (2008), when they found that the mechanical soil scarification did not promote the increase in bean yield, but showed to be effective in decreasing the effects of compaction on the soil surface layer, especially in the reduction of soil penetration resistance.
However, in an oxisol and in the same climate conditions, Almeida et al. (2008) found that a higher productivity of bean grains occured after the previous growth of Crotalaria juncea in relation to Pennisetum glaucum, possibly because Crotalaria juncea had generated more favorable enviroment to bean nodulations, providing the highest grain yield. Confirming the study by Oliveira et al. (2002), in which the authors found that the yield of common bean grains in the no-tillage system is influenced by different hays of green manures, in general, the bean crop in winter proved to be good alternative of crop succession and could add value, according to Silveira et al. (2001). In addition, the crop keeps the soil covered in the off season and uses nutrients from the previous biomass.

It was found that the previous cultivation of Cajanus cajan with and without mechanical soil scarification (Table 2), provided higher increases in grain yield (950 and $277 \mathrm{~kg}$ $\mathrm{ha}^{-1}$ ) and production values ( $\mathrm{R} \$ 723.11$ and $210.84 \mathrm{ha}^{-1}$ ) for rice crop. No increases in grain yield and production value were found in the other treatments in relation to fallow.

Table 2: Green manure (GM), mechanical decompactation (MD), quantities of seeds of green manure, yields (Y), increses in rice and beans yields, producitio value and costs with seeds + seeder + scarifier, per hectare

\begin{tabular}{|c|c|c|c|c|c|c|}
\hline \multicolumn{7}{|c|}{ Costs for upland rice crop - 2012/13 harvest } \\
\hline \multirow{3}{*}{ Green manure } & \multicolumn{3}{|c|}{ Treatments } & \multicolumn{3}{|c|}{ Addition } \\
\hline & MD & Quantity of seeds & $\mathbf{Y}$ & $\mathbf{Y}$ & Production value ${ }^{1 ; 2}$ & Costs $^{3}$ \\
\hline & & kg ha $^{-1}$ & $\mathrm{~kg} \mathrm{ha}^{-1}$ & kg ha $^{-1}$ & $\mathbf{R} \$$ ha $^{-1}$ & R\$ ha $\mathbf{A}^{-1}$ \\
\hline Fallow (control) & without & - & 4,877 & - & - & - \\
\hline Fallow (control) & with & - & 5,124 & - & - & 30.0 \\
\hline Cajanus cajan & without & 60 & 5,154 & 277 & 210.84 & 351.8 \\
\hline Cajanus cajan & with & 60 & 6,074 & 950 & 723.11 & 381.8 \\
\hline Crotalaria juncea & without & 30 & 4,532 & -345 & -262.60 & 252.5 \\
\hline Crotalaria juncea & with & 30 & 5,015 & -109 & -82.97 & 282.5 \\
\hline Urochloa ruziziensis & without & 12 & 4,118 & -759 & -577.73 & 129.8 \\
\hline Urochloa ruziziensis & with & 12 & 4,451 & -673 & -512.27 & 159.8 \\
\hline Pennisetum glaucum & without & 30 & 4,018 & -859 & -653.84 & 75.9 \\
\hline Pennisetum glaucum & with & 30 & 4,290 & -834 & -634.81 & 105.9 \\
\hline \multicolumn{7}{|c|}{ Cost for "Winter" bean crop - 2013 Harvest } \\
\hline Green manure & MD & Quantity of seeds & $\mathbf{Y}$ & $\mathbf{Y}$ & Production value ${ }^{1 ; 2}$ & $\operatorname{Cost}^{3}$ \\
\hline$\overline{\text { Fallow (control) }}$ & without & - & 1.824 & - & - & - \\
\hline Fallow (control) & com & - & 1.698 & - & - & 30,0 \\
\hline Cajanus cajan & without & 60 & 1.460 & -364 & -896.35 & 351.8 \\
\hline Cajanus cajan & com & 60 & 1.589 & -109 & -268.41 & 381.8 \\
\hline Crotalaria juncea & without & 30 & 1.649 & -175 & -430.94 & 252.5 \\
\hline Crotalaria juncea & com & 30 & 2.381 & 683 & 1681.89 & 282.5 \\
\hline Urochloa ruziziensis & without & 12 & 1.619 & -205 & -504.81 & 129.8 \\
\hline Urochloa ruziziensis & com & 12 & 1.907 & 209 & 514.66 & 159.8 \\
\hline Pennisetum glaucum & without & 30 & 1.693 & -131 & -322.59 & 75.9 \\
\hline Pennisetum glaucum & com & 30 & 2.158 & 460 & 1132.75 & 105.9 \\
\hline
\end{tabular}

${ }^{1}$ Based on average price paid in the state of São Paulo, rice in the 2012/13 harvest, R\$ 45.67 per 60 kg-bag and beans in the 2013 winter, $\mathrm{R} \$ 147.49$ per $60 \mathrm{~kg}$ bag (IEA, 2015). ${ }^{2}$ Price of scarification operations $\left(\mathrm{R} \$ 60.00 /\right.$ hour.ha $\left.^{-1}\right)$ and green manure sowing $\left(\mathrm{R} \$ 100.00 / \mathrm{hour}^{-h a^{-1}}\right.$ (AGRIANUAL, 2014); ${ }^{3}$ Costs with seeds + mechanical sowing of green manure + soil mechanical scarification. 
Marked increases were found in bean yield and production values (Table 2) grown with previous cultivations of Crotalaria juncea $\left(683 \mathrm{~kg} \mathrm{ha}^{-1}\right.$ and $\mathrm{R} \$$ 1,681.89 $\mathrm{ha}^{-1}$ ) and Pennisetum glaucum (460 kg ha-1 and $\mathrm{R} \$ 1,132.75 \mathrm{ha}^{-1}$ ) with no mechanical soil scarification with increases in grain yield of $40.22 \%$ and $27.09 \%$, respectively, followed by Urochloa ruziziensis cultivation with scarification (209 $\mathrm{kg} \mathrm{ha}^{-1}$ and $\mathrm{R} \$ 514.66 \mathrm{ha}^{-1}$ ) with less expression of grain yield $(12.31 \%)$. No increases were found in grain yield and and production value in the other treatments. This higher grain yield increase in the previous Crotalaria juncea growth was probably due to rapid decomposition of plant residues left on the soil surface and also because it presents low carbon (C)/nitrogen (N) ratio, where $\mathrm{N}$ is faster released in the soil, coinciding with the period of the highest demand of the crop (Oliveira et al., 2002).

By analyzing the costs (green manure seeds + mechanical operations of sowing and mechanical soil scarification) for the cultivation of rice and beans (Table 2), it was found that the highest costs occurred in the previous cultivation of Cajanus cajan, regardless of scarification, providing a higher cost values $\left(\mathrm{R} \$ 703.6 \mathrm{ha}^{-}\right.$ ${ }^{1}$ and $\mathrm{R} \$ 763.6 \mathrm{ha}^{-1}$ ) for rice and beans in succession. The lowest cost values were obtained with the cultivation of Pennisetum glaucum, regardless of scarification ( $\mathrm{R} \$ 151.9$ $\mathrm{ha}^{-1}$ and $\mathrm{R} \$ 211.9 \mathrm{ha}^{-1}$ ) for presenting lower cost of seeds ( $\mathrm{R} \$ 1.73 \mathrm{~kg}^{-1}$ of seeds) in relation to other green manures.

In relation to the profit margin for rice crop (Figure 1A), it was found that most of the treatments had a negative profit margin, except the previous cultivation of Cajanus cajan with mechanical soil scarification ( $\left.\mathrm{R} \$ 341.33 \mathrm{ha}^{-1}\right)$, thus they did not economically respond to adopted soil management practices. This was a short-term study, requiring further evaluations in the medium and long term of this soil management technology in no-tillage system established in lowland Brazilian Savannah.

Regarding to profit margin for the "winter" bean crop (Figure 1B), it was observed that the bean crop in succession to Crotalaria juncea (R\$1,399.39 ha-1) and Pennisetum glaucum (R $\left.\$ 1,026.8 \mathrm{ha}^{-1}\right)$ in the presence of mechanical soil scarification, followed by rice crop,
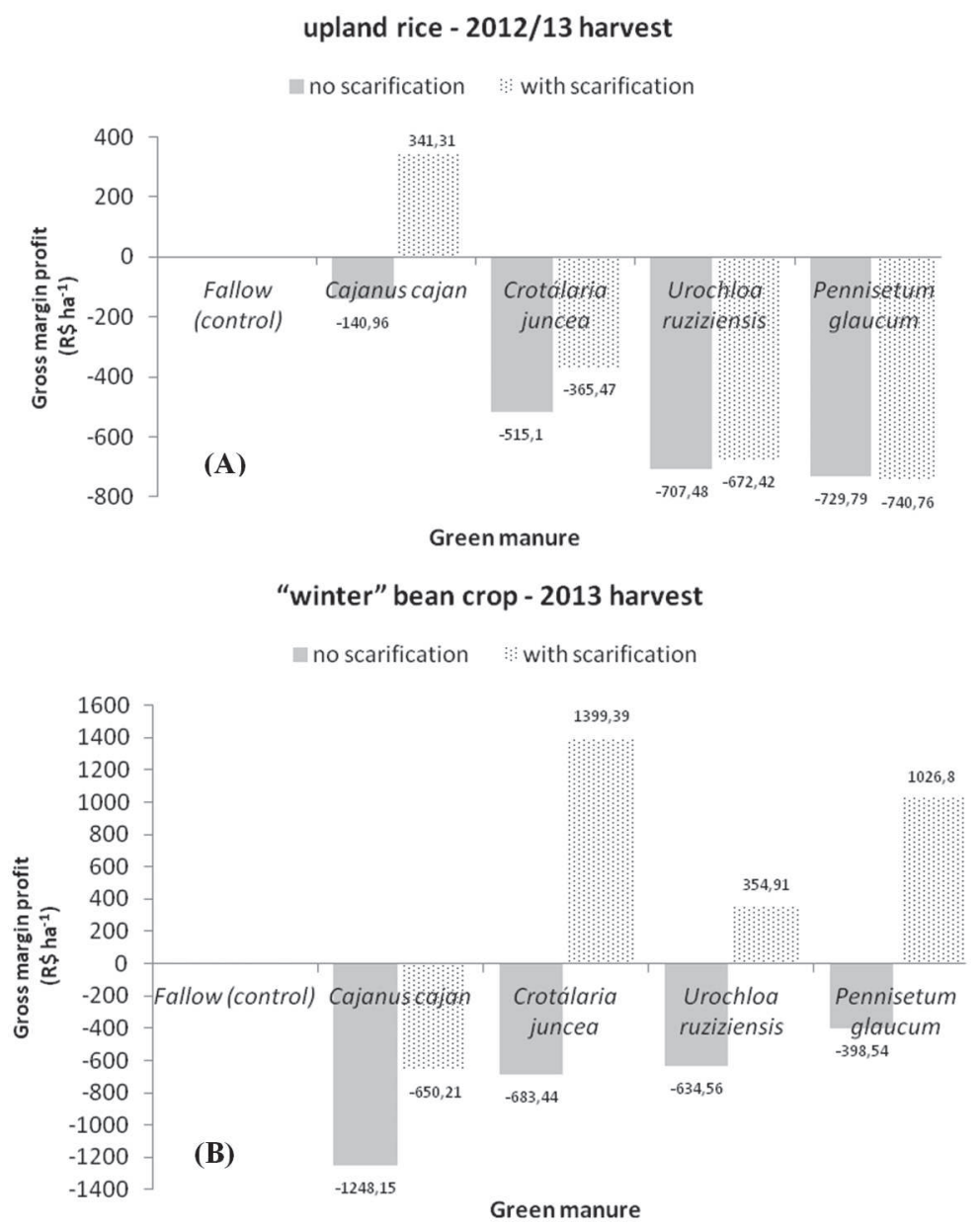

Figure 1. Gross profit margin $\left(\mathrm{R} \$ \mathrm{ha}^{-1}\right)$, in the previous cultivations of green manure in spring and soil mechanical decompactation in upland rice (A) and "winter" beans (B), under sprinkler irragation in a non-tillage system established 12 years ago in the lowland Savannah. 
provided higher profit margins compared to other green manures studied. The previous cultivation of Cajanus cajan, in the presence of mechanical soil scarification, was costly for the bean crop due to the use of larger quantity of seeds $\left(60 \mathrm{~kg} \mathrm{ha}^{-1}\right)$ and the high cost of seed $(\mathrm{R}$ $\left.\$ 10.06 \mathrm{~kg}^{-1}\right)$, provided less profit margin.

\section{CONCLUSIONS}

The yield of upland rice and "winter" beans were not influenced by the previous crop of green manure in the spring.

The upland rice grown in succession to Cajanus cajan in the presence of mechanical soil scarification, provided higher grain yield and higher margin gross profit.

"Winter" beans grown in succession to Crotolaria juncea and Pennisetum glaucum in the presence of mechanical soil scarification, followed by rice cultivation, provided greater increases in yields and gross profit margins.

\section{ACKNOWLEDGMENTS}

To FAPESP and CNPq for the financial support and by granting scolarships for doctorate to the first author by FAPESP, Process: 2012/05945-0.

\section{REFERENCES}

Agrianual (2014) Anuário da agricultura brasileira. São Paulo, Editora Agors. 460p.

Almeida VP, Alves MC, Silva EC \& Oliveira SA. (2008) Rotação de culturas e propriedades físicas e químicas em Latossolo Vermelho de Cerrado sob preparo convencional e semeadura direta em adoção. Revista Brasileira de Ciência do Solo, 32:12271237.

Alvarenga RC, Costa LM, Moura Filho W \& Regazzi AJ (1995) Características de alguns adubos verdes de interesse para a conservação e recuperação de solos. Pesquisa Agropecuária Brasileira, 30:175-185.

Ambrosano EJ, Tanaka RT, Mascarenhas HAA, Quaggio JÁ \& Cantarella H (1997) Leguminosas e oleaginosas. In: Raij B, Cantarella H, Quaggio JA \& Furlani AMC (Eds.) Recomendações de adubação e calagem para o Estado de São Paulo. $2^{\mathrm{a}}$ ed. Campinas, IAC. p.187-203. (Boletim Técnico,100).

Andrioli I (2004) Plantas de cobertura do solo em pré-safra a cultura do milho em plantio direto, na região de Jaboticabal-SP. Tese de Doutorado. Universidade Estadual Paulista "Julio de Mesquita Filho", Jaboticabal. 78p.

Araújo AG, Casão Junior R \& Siqueira R (2001) Mecanização do plantio direto: Problemas e soluções. Londrina, IAPAR, $18 \mathrm{p}$. (Circular Técnica, 137).

Bertin EG, Andrioli I \& Centurion JF (2005) Plantas de cobertura em pré-safra ao milho em plantio direto. Acta Scientiarum, 27:379-386.

Binotti FFS, Arf O, Cardoso ED, Sá ME, Buzetti S \& Nascimento V (2010) Fontes e doses de nitrogênio em cobertura no feijoeiro de inverno irrigado no sistema plantio direto. Bioscience Journal, $26: 770-778$.
Boer CA, Assis RL, Silva GP, Braz AJBP, Barroso ALL, Cargnelutti Filho A \& Pires FR (2007) Ciclagem de nutrientes por plantas de cobertura na entressafra em um solo de cerrado. Pesquisa Agropecuária Brasileira, 42:1269-1276.

Brasil (2013) Ministério da Agricultura, Pecuária e Abastecimento. Informações sobre a cultura do feijão. Disponível em: <http/ /www.agricultura.gov.br>. Acessado em: 17 de jullho de 2013.

Brazaca SGC, Salgado JM, Mancini Filho J \& Novaes NJ (1996) Avaliação física, química, bioquímica e agronômica de cultivares de feijão-guandu (Cajanus cajan (L) Mill). Alimentos e Nutrição, 7:37-45.

Câmara RK \& Klein VA (2005) Escarificação em plantio direto como técnica de conservação do solo e da água. Revista Brasileira de Ciência do Solo, 29:789-796.

Cantarella H \& Furlani PR (1996) Arroz de sequeiro. In: Raij BV, Cantarella H, Quaggio JA \& Furlani AMC (Eds.) Recomendações de adubação e calagem para o Estado de São Paulo. $2^{\mathrm{a}}$ ed. Campinas, IAC. 285p.

Carvalho MAC, Soratto RP, Athaydes MLF, Arf O \& Sá ME (2004) Produtividade do milho em sucessão a adubos verde no sistema de plantio direto e convencional. Pesquisa Agropecuária Brasileira, 39:47-53.

Collares GL, Reinert DJ, Reichert JM \& Kaiser DR (2008) Compactação de um Latossolo induzida pelo tráfego de máquinas e sua relação com o crescimento e produtividade de feijão e trigo. Revista Brasileira de Ciência do Solo, 32:933-942.

Conab (2015) Acompanhamento da safra brasileira de grãos 2014/ 2015: quarto levantamento - Janeiro/2015. Disponível em: <http://www.conab.gov.br>. Acessado em: 15 de março de 2015.

Crepaldi SA (1998) Contabilidade rural: uma abordagem decisorial. $2^{a}$ ed. São Paulo, Atlas. 352p.

Embrapa - Empresa Brasileira de Pesquisa Agropecuária (2013) Sistema brasileiro de classificação de solos. $3^{\text {a }}$ ed. Brasília, Embrapa. 353p.

FAO - Food and Agriculture Organization of the United Nations (2011) Food Outlook: global market analysis. Disponível em: <http:// http://www.fao.org/docrep/016/a1993e/al993e00.pdf>. Acessado em: 15 de março de 2015.

IEA - Instituto de Economia Agrícola (2015) Preços médios mensais pagos pela agricultura. Disponível em: <http:// www.iea.sp.gov.br/out/index.php>. Acessado em: 19 de janeiro de 2015.

Lara Cabezas WAR, Alves BJR, Caballero SSU \& Santana DG (2004) Influência da cultura antecessora e da adubação nitrogenada na produtividade de milho em sistema semeadura direta e solo preparado. Ciência Rural, 34:1005-1013.

Noronha JF (1987) Projetos agropecuários: administração financeira, orçamento e avaliação econômica. $2^{\mathrm{a}}$ ed. São Paulo, Atlas. 269 p.

Oliveira TK, Carvalho GJ \& Moraes RNS (2002) Plantas de cobertura e seus efeitos sobre o feijoeiro em plantio direto. Pesquisa Agropecuária Brasileira, 37:1079-1087.

Pacheco LP, Barbosa JM, Leandro WM, Machado PLOA, Assis RL, Madari BE \& Petter FA (2013) Ciclagem de nutrientes por plantas de cobertura e produtividade de soja e arroz em plantio direto. Pesquisa Agropecuária Brasileira, 48:1228-1236.

Pacheco LP, Leandro WM, Machado PLOA, Assis RL, Cobucci T, Madari BE \& Petter F (2011) Produção de fitomassa e acúmulo e liberação de nutrientes por plantas de cobertura na safrinha. Pesquisa Agropecuária Brasileira, 46:17-25. 
Reichert JM, Kaiser DR Reinert DJ \& Riquelme FB (2009) Variação temporal de propriedades físicas do solo e crescimento radicular de feijoeiro em quatro sistemas de manejo. Pesquisa Agropecuária Brasileira, 44:310-319.

Sabundjian MT, Arf O, Tarsitano MAA, Kaneko FH \& Corsini DCDC (2014) Análise econômica da adubação nitrogenada em feijoeiro de inverno sob plantio direto. Pesquisa Agropecuária Tropical, 44:349-356.

Salton JC, Hernani LC \& Fontes CZ (1998) Sistema Plantio Direto. O produtor pergunta, a Embrapa responde. Brasília, Embrapa. $248 \mathrm{p}$.

Silveira PM, Silva OF, Stone LF \& Silva JG (2001) Efeito do preparo do solo, plantio direto e rotação de culturas sobre o rendimento e economicidade do feijoeiro irrigado. Pesquisa Agropecuária Brasileira, 36:257-263.

Silva EC, Muraoka T, Monteiro ROC \& Buzetti S (2007) Análise econômica da adubação nitrogenada no milho sob plantio direto em sucessão a plantas de cobertura em Latossolo Vermelho. Acta Scientiarum Agronomy, 29:445-452.
Tanaka RT, Mascarenhas HAA, Dias OS, Campidelli C \& Bulisani EA (1992) Cultivo da soja após incorporação de adubo verde e orgânico. Pesquisa Agropecuária Brasileira, 27:1477-1483.

Teixeira Filho MCM, Tarsitano MAA, Buzetti S, Bertolin DC, Colombo AS \& Nascimento V (2010) Análise econômica da adubação nitrogenada em trigo irrigado sob plantio direto no cerrado. Revista Ceres, 57:446-455.

Vieira ML (2006) Propriedades físico-hídrico-mecânicas do solo e rendimento de milho submetido a diferentes sistemas de manejo. Dissertação de Mestrado. Universidade de Passo Fundo, Passo Fundo. 104p.

Villamil MB, Bollero GA, Darmody RG, Simmons FW \& Bullock DG (2006) No-till corn/soybean systems including winter cover crops: Effects on soil properties. Soil Science Society of America Journal, 70:1936-1944. 